\title{
Media Dan Ict Dalam Problematika Dakwah
}

\author{
Bahrur Rosi \\ STAI Miftahul Ulum Pamekasan
}

\begin{abstract}
Da'wah is a noble activity in invite and exhorts others towards goodness, the methods and the material presented must be able to embrace and accommodate all the things required by the partners of da'wah in all its religious activities. Thus indirectly demanded the existence of adjustment always preach, from the method of delivery, the message or the medium used. The world preaching experience challenges that are increasingly heavy, especially the development of science and technology which is always directly proportional to the problems faced by mankind as a user of the product and the technology itself. The entanglement between the Da'wah with advances in science, technology and communication media very closely. It is because of the possibility to fill in between the two, in the sense of communication media can be a means for Da'wah to be able to spread the content of dakwahnya in order to reach out to places that are difficult to be accessed are not likely to accessible directly by their da'i. Such is the case with events, can be useful as a control over the content displayed by the communications media so that more unscrupulous and in accordance with the rules and customs that apply in the community.
\end{abstract}

Keyword: Dakwah, ICT, Media, Teknologi

\section{Pendahuluan}

Dakwah merupakan aktivitas mulia dalam mengajak dan menyeru orang lain menuju kebaikan, metode dan materi yang dibawakan harus bisa merangkul dan mengakomodir semua hal yang dibutuhkan oleh mitra dakwah dalam semua aktivitas keagamaannya. Dengan demikian secara tidak langsung menuntut selalu adanya penyesuaian dari dakwah, mulai dari metode penyampaiannya, pesan yang disampaikan ataupun media yang digunakan. Dunia dakwah mengalami tantangan yang semakin berat, terutama perkembangan ilmu pengetahuan dan teknologi yang selalu berbanding lurus dengan permasalahan yang dihadapi oleh manusia selaku pengguna dari produk teknologi itu sendiri.

Perubahan dalam proses komunikasi manusia merupakan akar utama dari terjadinya fenomena-fenomena menarik dalam perjalanan dakwah islamiyah, Proses komunikasi yang selama ini dilakukan hanya melalui komunikasi tatap muka, komunikasi kelompok, komunikasi massa, berubah total dengan perkembangan teknologi komunikasi dewasa, khususnya internet. 
Perubahan tersebut akan membawa konsekuensi-konsekuensi proses komunikasi. Proses komunikasi yang terjadi membawa konsekuensi di tingkat individu, organisasi, dan kelembagaan yang pada akhirnya berimbas pula pada proses pelaksanaan dakwah.

Perkembangan ilmu pengetahuan dan teknologi pada dasarnya tidak hanya menimbulkan efek negative semata, tapi juga bisa menjadi sarana penunjang dan pendukung dari semua aktivitas positif manusia. Akan tetapi untuk menonjolkan efek positive seperti dimaksud perlu adanya upaya maksimal yang tidak bisa dipandang sebelah mata. Oleh karena itu, maka perlu adanya pengawasan dan kontrol maksimal dalam upaya menyelaraskan efek positif media teknologi dengan fenomena yang dihadapi masyarakat yang semakin komplek.

Keterikatan antara dakwah dengan kemajuan ilmu pengetahuan, teknologi dan media komunikasi sangat erat sekali. Hal itu dikarenakan adanya kemungkinan untuk saling mengisi antara keduanya, dalam arti media komunikasi bisa menjadi sarana bagi dakwah untuk dapat menyebarkan konten dakwahnya supaya bisa menjangkau tempat-tempat yang sulit untuk diakses yang tidak mungkin untuk didatangi secara langsung oleh para da'i. Demikian halnya dengan dakwah, bisa berguna sebagai kontrol terhadap konten yang ditampilkan oleh media komunikasi supaya lebih bermoral dan sesuai dengan peraturan dan adat istiadat yang berlaku di masyarakat.

Tulisan singkat ini akan menjelaskan tentang media sosial baru yang menjadi faktor utama dari semua perubahan pola dan proses komunikasi di masyarakat yang dilengkapi dengan analisis tentangperlunya perubahan yang signifikan dalam dakwah untuk mengimbangi kemajuan media teknologi informasi.

\section{Termenologi Media}

1. New Media

New media adalah komunikasi digital dan saluran informasi yang memungkinkan pengguna menjadi aktif dan mempunyai tingkah laku tersendiri dan unik didalam proses komunikasi digital tersebut yang tanpa batas lokasi maupun waktu. Karakteristik dari new media tersebut adalah Digital, Pro-Active, Visible, Real-Time And Memory, Ubiquitous, Dan Network. ${ }^{1}$

Tidak bisa dipungkiri kehadiran media sosial telah mengubah, bahkan merevolusi proses komunikasi manusia. Bahkan bisa dikatakan proses komunikasi model demikian merupakan ciri khas yang melekat pada masyarakat modern saat ini dan sangat mungkin dalam beberapa dekade

${ }^{1}$ Thorsten Hennig-Thurau, Edward C. Malthouse, Christian Friege, Sonja Gensler, Lara Lobschat, Arvind Rangaswamy, and Bernd Skiera The Impact of New Media on CustomerRelationships, , Journal of Service Research13(3) 311-330 
kedepan ada perubahan, tetapi untu ksaat sekarang media sosial berperan dalam penyebaran informasi. ${ }^{2}$

Apa yang terjadi pada media komunikasi penyebaran pesan diatas tentu membawa konsekuensi perubahan pada masyarakat. Konsekuensi itu kemudian membentuk sebuah ciri khas yang berbeda dengan kenyataan masyarakat sekarang. Secara fisik, jumlah anggota, kuantitas lalu lintas pesan, jenis-jenis pesan berbeda dengan kenyataan masyarakat saat ini. Sebut saja ada bentuk masyarakat lain selain masyarakat riil yang dikenal secara konseptual atau kenyataan. Masyarakat itulah yang dinamakan masyarakat virtual (muncul akibat internet)

Secara definitif, masyarakat (nyata) adalah sebuah kehidupan masyarakat yang secara inderawi dapat dirasakan sebagai sebuah kehidupan nyata, dimana hubungan antar angggotanya dibangun melalui penginderaan. Jadi masyarakat nyata adalah masyarakat yang secara nyata bisa dibuktikan disekitar manusia, terutama menyangkut ciri-ciri fisik. Ciri fisik yang bisa dibuktikan itu misalnya ciri yang melekat pada individu, jumlah anggota dalam masyarakat itu, kegiatan, aturan-aturan, orientasi hidup, tuntutan dan dukungan dan dinamika yang lain. Misalnya, masyarakat Tengger (sekitar gunung Bromo), masyarakat Jawa, Sunda, Madura dan lain-lain.

Intinya, mereka bisa diindera keberadaannya. Sementara itu, ada masyarakat maya(virtual/cyber community) yang secara definitif bisa diartikan sebagai sebuah kehidupan masyarakat manusia yang tidak dapat secara langsung diindera melalui penginderaan manusia, namun dapat dirasakan dan disaksikan sebagai sebuah realitas. Mereka ini memakai seluruh metode kehidupan masyarakat nyata sebagai model yang dikembangkan di dalam segi kehidupan maya.

Sekadar menyebut contoh adalah mereka membangun interaksi sosial dan kehidupan kelompok, membangun stratifikasi sosial, membangun kebudayaan, membangun kekuasaan, wewenang dan kepemimpinan, membangun sistem kejahatan dan kontrol-kontrol sosial. Secara akar kata komunitas/masyarakat maya bisa ditelusuri dari pendapat William Gibson dalam novelnya berjudul Neuromancer. Ia mengenalkan istilah gyber space atau ruang hampa.

Cyberspace itu sendiri berarti ruangan hampa. Ruang hampa yang dimaksud di sini bukan ruang sebenarnya atau dunia nyata sebagaimana kita merasakan disekitar kita. Ruang hampa itu ruangan yang dibentuk karena pemakaian komputer. Komputer menciptakan ruang-ruang hampa. Ruang hampa ini terasa bentuknya sejak adanya multi media dengan perantaraan internet. Komunitas virtual khas istilah yang bisaa dipakai dalam lingkungan

${ }^{2}$ Nuruddin, Media Sosial Baru dan Munculnya Revolusi Proses Komunikasi, Jurnal Komunikator UMY :

Vol. 5, no. 2,127-142, November 2013 
akademis, sementara istilah gybe rspace untuk menunjuk pada istilah populer. Ada juga yang sering menyebut dengan istilah virtual reality yang berarti realitas yang merujuk pada lingkungan yang "menyelubungi"/ "menghidupkan secara sensual", yang diperoleh individu dengan jalan menghubungkan dirinya dengan komputer.

Disebut komunitas ruang hampa karena anggotanya berhadapan dengan ilusi. Anggota tidak berhadapan dengan anggota secara fisik sebagaimana masyarakat nyata. Mereka hanya berhadapan dengan layar komputer (misalnya), seolah berbicara, tertawa, tersenyum, sedih sendiri. Jika dilihat sekilas seperti orang gila. Tetapi mereka ini sedang berada dalam sebuah ruang imajinasi yang bisa berhubungan satu sama lain. Jangan heran pula jika komunitas virtual juga disebut komunitas semu (pseudo community).

Sebagai ciptaan manusia, masyarakat maya menggunakan seluruh metode kehidupan masyarakat nyata juga sebagai contoh model yang dikembangkan dalam masyarakat maya. Itu misalnya; (a)proses-prosessosial dan interaksi, (b)kelompok sosial maya,(c) pranata dan kontrolsosial, (d)stratifikasi sosial,(e)perubahan sosial ${ }^{3}$

\section{Online Communities}

Komunitas adalah kelompok organisme atau manusia yang hidup dan saling berinteraksi di daerah tertentu. ${ }^{4}$ Adapun yang dimaksud komunitas online apabila mengacu pada definisi seperti diatas menunjukkan bahwa arti yang dimaksud adalah sekelompok manusia yang hidup dan saling berinteraksi dalam suatu wadah perkumpulan tertentu di suatu grup dalam media social.

Sejalan dengan perkembangan zaman, ruang publik telah meluas melampaui ranah fisik dan geografis yang dapat dinikmati secara langsung dan normal. Informasi dan teknologi komunikasi telah berkembang pesat di kota-kota besar di Indonesia dalam dua dekade terakhir. Saat ini, dengan kecanggihan teknologi, ruang publik juga hidup di dunia maya. Hal ini membuat perubahan dalam berkegiatan sosial-budaya, ekonomi, sosial politik, dan kelembagaan terutama di perkotaan. Terciptanya bentuk konektivitas baru antar manusia yang tidak lagi terbatas oleh kehadiran fisik dan letak geografis. Muncullah fenomena komunitas yang semakin umum dikenal sebagai komunitas jejaring.

Kemudahan mengunduh aplikasi di internet mempermudah penggunanya untuk membentuk komunitas online berdasarkan kesamaan kepentingan dan ketertarikan. Komunitas online adalah kumpulan orang (masyarakat) yang melakukan kegiatan dalam bentuk pertukaran informasi

\footnotetext{
${ }^{3}$ Burhan Bungin,. Sosiologi Komunikasi : Teori, Paradigma,dan Diskursus Teknologi Komunikasi di Masyarakat. Jakarta: Kencana. 2007

${ }^{4}$ Kamus besar bahasa Indonesia digital
} 
dan pengetahuan dengan bantuan Information and Communications Technology (ICT). Komunitas online dapat dibentuk dengan hanya beberapa orang atau anggota yang terbatas. Beberapa contoh komunitas online misalnya komunitas alumni atau hobi. Komunitas ini menjadi contoh bahwa konektivitas tidak terbatas oleh pertemuan secara fisik, bisa juga melalui dunia maya. Ini adalah fenomena menarik untuk dikaji karena jenisnya beragam, walaupun pada kenyataannya, kegiatan ini masih memerlukan pertemuan fisik secara real time dan ruang. Keberadaan komunitas online ada yang bertahan lama atau hanya sementara. Minat yang mendorong pembentukan komunitas online adalah representasi dari aktualisasi diri manusia yang tidak cukup dengan memenuhi kebutuhan primer dan sekunder di dunia nyata ${ }^{5}$. Kecenderungan terhadap penggunaan facebook, twitter, path, mailing list, whatsapp dan lainnya memperlihatkan bahwa anggota kelompok online tidak tunggal, namun bisa terdiri dari berbagai macam latar belakang. ${ }^{6}$

Maka dari itu, dengan semakin banyaknya komunitas online yang tersedia, maka sangat besar peluang yang dimiliki oleh para da’i untuk memperlebar sayap dakwahnya dengan memanfaatkan berbagai macam media dan ketersediaan ruang yang begitu besar untuk digarap sebagai ladang segar untuk memperluas cakupan dakwahnya.

3. Value Chain

Salah satu ciri khas dari new media seperti yang disebutkan diatas adalah adanya pergeseran rantai nilai, maksudnya semua pengguna media sosial bisa saling bertukar posisi sebagai penyedia, pengguna dan lain sebagainya. Perubahan rantai nilai tidak terbatas seperti yang disebutkan di depan, akan tetapi juga meliputi berbagai aspek, seperti adanya penurunan harga produksi, lebih mudahnya proses distribusi dan lain sebagainya.

$V$ alue Chain atau rantai nilai dalam industri tradisional berjalan secara linear, teratur dan monoton, dan dapat dipahami sebagai suatu yang terjadi secara berurutan dan selalu sama setiap saat dengan mengikuti keteraturan alur yang mesti dilewati, mulai dari proses pembuatan konten, bundling sampai pendistribusianya. Bahkan Interaksi yang terjadi antara konsumen dengan produsen/distributor hanya terjadi secara Door to Door. ${ }^{8}$

Sedangkan Value Chain di era industri digital sudah berevolusi kearah yang lebih fleksibel, di era ini tidak lagi se-njelimet seperti di era tradisional

${ }^{5}$ Williams, RN And Slife BD. (1995) what's behind the reseacrch : discovering hidden assumptions in the behavioral sciences, sage publication. Inc, Printed in the United States of America

${ }^{6} \mathrm{http}: / /$ membacaruang. $\quad$ com/komunitas-online-di-era-media-sosial-dan-perannya-dalammenciptakan-ruang-publik/

${ }^{7}$ E-journal, Part $3 / 8$ Industry Transformation - Horizon Scan: ICT \& the Future of Media

${ }^{8}$ Part 3/8 Industry Transformation - Horizon Scan: ICT \& the Future of Media 
yang harus melewati tahapan demi tahapan secara teratur. Bahkan perubahannya bukan hanya dalam hal itu, tatapi juga dalam pembiayaan yang menjadi lebih murah atau bahkan gratis, dan dalam hal keterlibatan konsumen yang lebih komplek di berbagai kegiatan dan proses industri

Demikian juga halnya dengan terjadinya perubahan pola dan cara berkomunikasi masyarakat modern yang selalu memanfaatkan ketersediaan media komunikasi digital yang mereka miliki, yang pada prosesnya dikatakan sebagai revolusi teknologi komunikasi atau revolusi teknologi informasi.

Revolusi teknologi informasi menyebabkan orang dengan cepat mengetahui berita dan dengan cepat pula mengirimkan berita, jadi terciptalah komunikasi yang efektif. Orang berusaha menanggapinya, memperbaiki apa yang ada, meningkatkannya dan menciptakan hal yangbaru. Dan terjadilah perkembangan yang berantai. Revolusi informasi tidak hanya merubah proses memperoleh berita, dan sulit menjadi mudah melainkan melahirkan alat, teknik-teknik dan mesin yang dibuat ditempat lain yang diketahui serta dimengertinya dengan jelas dari informasi (dariuraian dan lukisan dimajalah, TV, selebaran dan sebagainya). Dalam revolusi industri, kereta api memperpendek waktu yangdiperlukan untuk melalukan perjalanan, termasuk perjalanan berita dari beberapa hari menjadi beberapa jam.

Kini revolusi teknologi informasi memperpendek waktuitu secara lebih drastis. Suatu berita dapat mencapai keseluruh dunia dalam waktu beberapa menit lewat berita yang cepat dari berbagai penemuan. Demikianlah revolusi teknologi informasi mempengaruhi berbagai segi kehidupan. Teknologi informasi dan komunikasi banyak mempengaruhi setiap unsur ranta inilai, mengubah cara melaksanakan kegiatan bernilai, serta mengubah hubungan antar kegiatan tersebut. Teknolgi informasi menyebabkan komunikasi jarak jauh dapat dilakukan dengan mudah. ${ }^{9}$

Perubahan rantai nilai seperti dipaparkan diatas akan sangat bermanfaat terhadap efektifitas dan efisiensi pelaksanaan dakwah islamiyah, karena diakui atau tidak kendala utama dari tidak maksimalnya pelaksanaan dakwah islamiyah dimaksud disebabkan oleh terbatasnya ruang dan waktu yang dimiliki oleh para da'i, hal itu belum lagi ditambah dengan keterbatasan dana yang selalu menjadi masalah klasik dalam setiap agenda dakwah.

\section{Fenomena Kehidupan Masyarakat Modern Dan Tantangan Dakwah}

Perkembangan gaya hidup masyarakat modern berjalan Seiring dengan perkembangan teknologi informasi, hal itu karena masyarakat modern hampir tidak mungkin untuk dipisahkan dari media teknologi komunikasi (Gatged, HP,

${ }^{9}$ Fachmi Tamzil,Peran Teknologi Informasi Dalam Dunia Komunikasi, Universitas Esa Unggul http://www. esaunggul. ac. id, 09-03-2012 
dll), mereka seakan tidak dapat bertahan hidup kalau tidak menggunakan media tekhnologi komunikasi tersebut.

Teknologi komunikasi telah menjelma sebagai best friend buat manusia, mereka tidak mempermasalahkan kesendirian selagi mereka bisa mengakses media teknologi komunikasi, bahkan lebih parah lagi mereka asik dengan "dunia mereka sendiri" saat berada ditengah keramaian. Mereka sudah lebih suka berinteraksi dengan orang yang ada ditempat yang jauh daripada dengan mereka yang berada disekitarnya, walaupun "mungkin" memang mereka yang berada ditempat jauh itulah yang lebih dekat dengan mereka secara interaksi sosial.

Manusia (masyarakat Indonesia khususnya) cenderung merasa takjub dengan content-content baru yang terdapat dalam media teknologi komunikasi, sehingga mereka seperti memiliki keinginan yang kuat untuk "awalnya mungkin hanya mencoba" tapi hal itu menggiring mereka untuk meniru semua hal yang di publikasikan didalam media tersebut. Mereka sudah mulai abai terhadap nilai yang terkandung dalam content tersebut, dan hanya memperhatikan kesenangan yang bisa mereka dapat dari apa yang terdapat didalamnya.

Keadaan yang mengalami perubahan yang sangat cepat dan komplet seperti disebut diatas, sangat memberikan dampak yang teramat besar terhadap pergeseran nilai yang ada pada masyarakat. Perubahan seperti ini memberikan tantangan yang komplit dan mencakup semua aspek dalam pelaksanaan dakwah terhadap masyarakat dimaksud. Tidak hanya tentang kehidupannya yang riil tapi juga tentang kehidupannya di dunia maya.

Pada satu sisi ketersediaan media teknologi komunikasi memberikan pengaruh yang cukup positif terhadap pelaksanaan dakwah, antara lain kemudahan dan efisiensi baik biaya maupun waktu, tidak terbatas oleh ruang dan bisa menjangkau semua lapisan masyarakat tanpa harus ada sekat. Namun dibalik dampak positif yang dihasilkan, tidak dapat dipungkiri bahwa keberadaan media teknologi dan komunikasi juga memberikan tantangan tersendiri terhadap para pelaku dakwah, diantaranya materi dakwah yang disampaikan harus mampu mengakomodasi setiap permasalahan yang dihadapi oleh masyarakat modern yang semakin komplit. Disamping itu keberadaan dakwah harus dilakukan dengan konten yang lebih menarik agar bisa menyaingi kontenkonten lain yang lebih cenderung mengarah pada hal yang kurang positif.

\section{Dakwah Menjadi Semakin Variatif Dan Fleksibel}

Dahulu kalau berbicara dakwah, maka yang terlintas didalam fikiran kita adalah seorang ustad yang berdiri diatas mimbar dengan para mustami'in berada didepannya, Itu sebelum terjadinya era komunikasi informasi. Akan tetapi seiring perkembangan media teknologi dan komunikasi dakwah tidak lagi harus di dalam masjid, tidak harus lagi diatas mimbar, tetapi sudah bisa dilakukan sambil tiduran di dengan menggunakan gatged dan sebagainya. Kalau 
dulu harus menempuh waktu yang sangat lama untuk mencapai tempat yang terpencil, sekarang hanya butuh waktu sepersekian detik dengan menggunakan akses internet. Kalau dulu dakwah hanya berupa teriakan-teriakan dari suara Keterikatan antara dakwah dengan kemajuan ilmu pengetahuan, teknologi dan media komunikasi sangat erat sekali. Hal itu dikarenakan adanya kemungkinan untuk saling mengisi antara keduanya, dalam arti media komunikasi bisa menjadi sarana bagi dakwah untuk dapat menyebarkan konten dakwahnya supaya bisa menjangkau tempat-tempat yang sulit untuk diakses yang tidak mungkin untuk didatangi secara langsung oleh para da'i. Demikian halnya dengan dakwah, bisa berguna sebagai kontrol terhadap konten yang ditampilkan oleh media komunikasi supaya lebih bermoral dan sesuai dengan peraturan dan adat istiadat yang berlaku di masyarakat. da'i, sekarang bisa berupa tulisan yang diposting di blog, berupa pesan singkat lewat BBM, WA dan atau status yang terpangpang diakun facebook dan sebagainyaa. Dakwah bisa juga berupa video yang diunggah di youtube atau dikirim via email dan sebagainya.

Semakin beragamnya media yang tersedia akan semakin memberikan banyak opsi kepada da'i untuk menyampaikan pesan dakwahnya secara maksimal, walaupun sebenarnya keberadaan media dakwah bukanlah penentu utama bagi kegiatan dakwah, akan tetapi media ikut memberikan andil yahng besar untuk kesuksesan dakwah. ${ }^{10}$ Memang pada hakikatnya keberadaan media hanya sebagai penunjang dan bukan sebagai penentu,karena pada hakikatnya unsur utama dalam pelaksanaan dakwah tetaplah bergantung pada kemampuan da'i atau pendakwah dalam mengelola penyampaian dakwahnya.

Selain itu, dakwah juga bisa menggunakan media-media digital, seperti ceramah pengajian yang disimpan di computer berupa Mp3, video, dan sebagainya. Dengan demikian, maka isi pengajian tidak akan mudah hilang. Jika kita lupa atau mau mendengarkan kembali maka tinggal di re-play saja. Semuanya menjadi mudah dan praktis. Lebih jauh lagi, sekarang telah beredar Al-Quran digital, hadist digital, dan buku-buku islami digital. Semuanya dibuat untuk memudahkan kita dalam memahami ajaran-ajaran agama. Misalnya, ketika kita akan mencari suatu tema dalam Al-Quran maka kita tidak mesti membuka lembar perlembar. Tetapi kita tinggal langsung masukkan kata kuncinya maka Al-Qur'an digital tersebut akan memunculkan hasil dari apa yang kita cari. Selain itu, dalam Al-Quran digital juga bisa diisi dengan audionya. Sehingga kita bisa membaca sekaligus mendengarkan bacaannya. Atas dasar itu, maka tidak ada salahnya jika kita mulai melirik dan menggunakan media-media ini untuk kepentingan dakwah - dengan tidak meninggalkan tradisi mengaji di masjid secara berjamaah. Tetapi media ini digunakan sebagai sarana pelengkap untuk berdakwah.

\footnotetext{
${ }^{10}$ Ali Azis, Ilmu Dakwah, Kencana, Jakarta,2004, Hal. 428
} 


\section{Problem Di Masyarakat Semakin Komplit}

Perkembangan IPTEK telah memungkin terciptanya banyak hal di hampir segala bidang. Di bidang TIK (ICT) telah memungkinkan munculnya media baru atau media konvergensi. Suatu hal yang menurut MC Luhan, menyebabkan teknologi itu menjadi determinisme yang mempengaruhi perubahan sosial dan khususnya perubahan budaya komunikasi di kalangan individu. $^{11}$

Sisi lain dari era teknologi komunikasi, kita dihadapkan pada suatu tantangan yang tidak ringan. Berkembang pesatnya media-media elektronik menciptakan perubahan pola dan gaya hidup masyarakatnya terutamapada masyarakatdi negara-negara yang sedang berkembang, seperti Indonesia. Pada negara-negara yang sedang berkembang, dengan adanya modernisasi mengakibatkan terjadinya transisi dalam kehidupan masyarakatdari bentuk tradisional menuju bentuk modern. Hal ini karena dilaksanakan industrialisasi, sekularisasi, diferensiasi struktural, spesialisasi fungsional, orientasi rasional; mengakibatkan perkembangan atau evolusi dari bentuk masyarakat tradisional yang sederhana, homogen danfolk menujumasyarakat perkotaan yang rumit dan heterogen. ${ }^{12}$

Ibarat dua sisi mata uang yang tidak mungkin untuk dipisahkan, dampak positif dan negatif yang dimiliki oleh setiap hal, mediapun bersifat demikian. Bahkan seiring perkembangan media yang semakin tak terbendung, konten negatif dalam media justru lebih mendominasi. ${ }^{13}$ Kenyataan seprti diatas tentu menjadi salah satu pemicu utama terhadap kondisi kehidupan modern ternyata rentan terhadap munculnya perilaku-perilaku yang menyimpang akibat sistem informasi yang terbuka, kebebasan individu, gaya hidup yang hedonik, dan sebagainya. Misalnya kasus yang sedang marak dinegeri kita sekarang ini, seperti kasus penyalahgunaan NAPZA yang semakin merajalela. ${ }^{14}$ Kasus korupsi baik di tingkat pemerintahan pusat maupun didaerah; kasus pembunuhan, kasus perkosaan, dan sebagainya. Hal tersebut tidak terlepas dari kondisi masyarakat yang belum bisa memaknai modernisasi itu sendiri. Kehidupan modern yang digambarkan oleh Gidden sebagai panser raksasa

\footnotetext{
${ }^{11}$ Mc Luhan, Marshal. 2003"Technology Determinism", In A First Look at Communication Theory, Fifth Edition, by EM Griffin, New York, McGraw Hill. 2003.

${ }^{12}$ Abraham,M. Francis. (1991). Modernisasi di Dunia Ketiga Suatu Teori Umum Pembangunan. (TerjemahanM. Rusli Karim). Penerbit:UniversityPressof America, (Bukua sliditerbitkan tahun 1980).

${ }^{13}$ AliAzis. Imu Dakwah edisi Revisi, Jakarta: Kencana, 2012. Hal. 432

${ }^{14}$ Kompas, 29Januari2013
} 
(Juggernaut) yang bila tidak terkendali maka akan mengancam kehidupan masyarakat modern itu sendiri. ${ }^{15}$

Berangkat dari fenomena seperti disebutkan diatas, maka dakwah harus benar-benar ditegakkan dengan content dan metode yang sangat menarik. Mengapa? karena dalam media tersebut mengandung beraneka ragam pesan yang negatif. Kita ambil contoh televisi, dari 24 jam siaran hanya 1 sampai 2 jam saja yang diperuntukkan untuk acara keagamaan - itupun pada waktu subuh. 22 sampai 23 jam sisanya diisi dengan acara yang tidak jelas isinya bahkan cenderung berbau dewasa dan kekerasan. Hal semacam ini tentunya sangat menghawatirkan bagi generasi muslim - terlebih anak kecil yang menontonnya. Bayangkan saja dalam sehari kebanyakan dari kita mengkonsumsi televisi 7-8 jam. Belum lagi acara yang disajikannya dipenuhi tayangan yang tidak baik seperti kekerasan, kesenonohan, kemusyrikan, dan mistik-mistik yang klasik. Dengan demikian, jika acara ini terus menurus ditonton setiap hari bukan hal yang tidak mungkin akan memberikan pengaruh yang dahsyat. Perubahan dan pergeseran pun akan menjadi keniscayaan baik secara kognitif, afektif, dan prilaku.

Hal diatas belum termasuk tantangan yang ditimbulkan oleh internet, yang kita tahu memiliki konten yang amat beragam dan komplit, bisa diakses kapan saja tanpa mengenal batasan waktu dan tempat, terlebih dengan adanya peningkatan jaringan dari yang semula hanya $3 \mathrm{G}$ menjadi $4 \mathrm{G} L T E$ yang semakin memberikan kenyamanan dalam mengakses data tanpa kenal "lemot" dan semacamnya.

Dengan keberagaman konten media yang semakin "tidak mungkin" terkontrol, otomatis konten dakwah yang mesti dijadikan sebagai pembanding juga harus ikut beragam dan mampu menyasar semua segmentasi pengguna media, hal itu tentunya menuntut da’i untuk ikut berperan aktif dalam menyediakanmateri dan konten dakwah yang sesuai dengan keadaan, status social dan gaya hidup mitra dakwah yang menjadi "ladang" dakwahnya.

\section{Dakwah Harus Tetap Berpijak Pada Al-Qur'an dan Al-Hadits}

Secara terminologis dakwah islam telah banyak didefinisikan oleh para ahli. Sayyid Qutb memberi batasan pengertian dakwah dengan "mengajak" atau "menyeru" kepada orang lain masuk kedalam sabil Allah SWT. Bukan untuk mengikuti da'i atau sekelompok orang. ${ }^{16}$ Dan juga menurut Prof. Toha Yahya Omar, M. A. bahwa dakwah adalah mengajak manusia dengan cara bijaksana

\footnotetext{
${ }^{15}$ Muzaini, Perkembangan Teknologi Dan Perilaku Menyimpang Dalam Masyarakat Modern,Jurnal Pembangunan Pendidikan: Fondasi dan Aplikasi Volume 2, Nomor 1, 2014

${ }^{16}$ Wahyu Ilaihi, Komunikasi Dakwah, (Bandung: Pt. Remaja Rosdakarya, 2010), Hal. 14
} 
kepada jalan yang benar sesuai dengan perintah tuhan,untuk keselamatan dan kebahagiaan mereka di dunia dan akhirat. ${ }^{17}$

Apabila berbicara tentang dakwah, maka secara tidak langsung kita membicarakan keidupan manusia dari berbagai aspek, baik aspek social, ekonomi, budaya dan lain sebagainya, hal itu tentu akan menghadapkan kita pada semua problem yang dialami manusia secara umum dari berbagai bidang kehidupan mereka. Untungnya kita memiliki al-qur'an dan hadits sebagai pegangan hidup, didalamnya termuat semua problem solving dari semua permasalahan yang dihadapi manusia.

Secara garis besar semua kegiatan dakwah harus tetap berpijak pada dasar-dasar agama seperti yang telah digariskan dalam al-qur'an dan hadits sebagai petunjuk dalam menyelesaikan persoalan-persoalan akidah syaria'ah, dan akhlak dengan jalan meletakkan dasar-dasar prinsipil mengenai persoalanpersoalan dimaksud. ${ }^{18}$ Namun, walaupun bersifat paten seperti itu, tapi secara praktek "mungkin" perlu sedikit pembaharuan dan modifikasi dalam cara menyampaikan pesan-pesan dakwah tersebut, demi tercapainya tujuan dakwah secara maksimal.

Adanya modifikasi dalam metode ataupun dalam content dakwah mutlak diperlukan mengingat sasaran yang menjadi mitra dakwah sangat beragam dan multi aspek, akan tetapi yang sangat penting untuk di utamakan adalah sumber dari dakwah haruslah diambil dari al-qur'an dan hadits mengingat hanya itulah yang menjadi warisan nabi terhadap umatnya, sebagaimana di sabdakan oleh Rasulullah SAW : ${ }^{19}$

تركت فيكم أمرين لن تضلو ا ما تمسكتم بهما كتاب الله وسنة نبيه صلى الله عليه وسلم "aku tinggalkan dua perkara kepadamu, yang engkau sekalian tidak akan tersesat selama berpegang teguh terbadap keduaanya, yaitu al-qur'an dan hadits" Sebagaimana juga disebutkan dalam ayat al-qur'an berikut : ${ }^{20}$

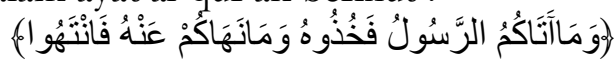

"dan apa yang diberikan rasul kepadamu, maka terimalah. Dan apa yang dilarangnya maka tinggalkanlab"

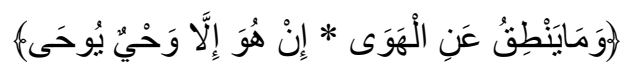

"Dan tiadalah apa yang diucapkan oleh rasul itu menurut kemanan hawa nafsunya. Ucapannya itu tiada lain hanyalah wabyu yang di wabyukan kepadanya"

Berangkat dari hadits dan ayat diatas, maka sangat penting bagi para da'i atau siapapun yang terpanggil untuk menjadi juru dakwah untuk mengetahui

\footnotetext{
17 Samsul Munir Amin, Ilmu Dakwah, (Jakarta: Amzah, 2009), Hal. 3

${ }^{18}$ M. Quraiys Shihab, "Membumikan" Al-Qur'an", Mizan, Bandung, cetakan XXVII, 2004. Hal. 33

${ }^{19} \mathrm{Abu}$ UmarYusuf bin Abdillah bin Muhammad bin Abdi al-Barri, al-tambid Lima fi Al-Munattho' min Ma'ani wa Al-Asaniid, Maktabah Ibnu Taimiyah

${ }^{20} \mathrm{Al}$-qur'an Digital Bahasa Indonesia, versi 3. 9.2
} 
dan memahami kandungan dari al-qur'an dan hadits secara mendalam melalui para ulama' yang sudah masyhur ke'alimannya. Hal ini bukan untuk dijadikan sebagai justifikasi bahwa yang boleh mengajarkan ilmu agama hanyalah para ulama' saja, melainkan sebagai bentuk "ihtiyath" supaya tidak terjerumus pada pemahaman yang salah sehingga menyebabkan "dhallun mudhillun" yang sangat dicela dalam agama.

Demikian juga dari ayat dan hadits diatas, maka dapat diambil pemahaman yang cukup jelas bahwa sebagai umat islam yang taat harus mempunyai inisiatif untuk mengikuti dan mengupayakan orang lain untuk juga mengikuti pada apa yang sudah dijelaskan oleh rasulullah tersebut. Penafsiran seperti ini didapat dari bentuk kata jama' yang dipakai dalam hadits dan ayat diatas. Maka berangkat dari pemikiran inilah, dapat ditarik suatu kesimpulan awal bahwa sebagai umat islam -secara tidak langsung- kita mendapat tanggung jawab untuk mengarahkan orang lain "yang belum sadar" kepada jalan yang diridhoi-Nya dengan cara berdakwah.

Dakwah mutlak dibutuhkan dalam upaya membangun manusia seutuhnya dalam arti membangun rohani maupun jasmaninya, karena pada dasarnya manusia tidak mungkin bisa membangun manusia yang lain hanya dengan mengandalkan pemikiran akal saja, karena manusia, dengan ilmu pengetahuan sebagai hasil pemikiran akalnya dari dahulu hingga sekarang belum berhasil mengetahui hakekat dirinya. Oleh karena itu, mau tidak mau, manusia harus memperhatikan petunjuk ajaran agama islam, apabila betul-betul beritikad baik untuk membangun manusia seutuhnya itu.

\section{Kendala Utama Adalah Sumber Daya Manusia}

Sumber daya manusia merupakan aset yang paling penting dalam upaya mencapai semua apa yang menjadi keinginan dan cita-cita dari manusia itu sendiri (tidak terecuali dengan dakwah). Dengan adanya sumber daya manusia yang memadai maka sumber daya-sumber daya yang lain akan dengan mudah untuk dikelola dan di manfaatkan sesuai dengan apa yang mereka inginkan.

Populasi manusia (khususnya warga Indonesia) yang tumbuh dengan begitu pesat akan menjadi beban apabila tidak diimbangi dengan peningkatan kwalitas manusia tersebut, beda halnya dengan peningkatan populasi yang dibarengi dengan peningkatan kwalitas sumber daya manusianya, maka akan menjadi potensi yang tidak hanya meningkatkan taraf hidup manusia yang bersangkutan tapi bisa juga berimbas pada lingkungan tempat tinggalnya.

Lingkungan tempat tinggal tidak hanya berarti tempat dimana kita berlindung dari panas dan hujan, tapi juga meliputi semua hal yang berkaitan dengannya, termasuk manusia yang ada disekitarnya. Manusia disini yang dimaksudkan adalah semua yang terlibat dalam kegiatan dakwah, baik sebagai 
da'i, maupun sebagai mad'u, semua perlu untuk mendapatkan perhatian yang serius demi mencapai terciptanya sumber daya yang maju.

Akan tetapi yang perlu untuk mendapat perhatian lebih sebenarnya terlatak pada keadaan SDM da'i yang kurang memadai, baik dalam penguasaan materi dakwah maupun dalam penguasaan teknologi komunikasi sebagai media dakwah, kongkritnya seperti ini ;

a. Para da’i senior banyak yang tidak memiliki kemampuan dalam mengoperasikan media \& ICT, itu dikarenakan mayoritas dari mereka merupakan alumni dari pesantren-pesantren salaf yang belum memberikan pembelajaran yang maksimal terkait pengetahuan teknologi komunikasi.

b. Para da'i muda banyak yang kurang kompetent dalam mendalami al-qur'an dan hadits, karena kebanyakan dari mereka adalah alumni perguruan tinggi yang "hanya mendalami media dakwah" kurang mendapatkan pengalaman yang cukup dalam pengetahuan agama, terutama tentang metodelogi tafsir al-qur'an dan hadits yang menjadi rujukan semua content dakwah.

Melihat realita yang ada seperti ini, tentunya harus mendapat perhatian yang serius dari para da'i untuk menjadikan dakwah sebagai problem solving dari semua mitra dakwah yang ada dengan cara meningkatkan SDM-nya demi tercapainya tujuan dakwah secara maksimal.

\section{Pengembangan Manusia Dalam Berbagai Aspek Menjadi Suatu Keniscayaan}

Upaya mengembangkan kwalitas sumber daya manusia adalah prasyarat tercapainya tujuan dakwah, dalam upaya ini minimal ada 3 dimensi yang harus diperhatikan, yaitu : ${ }^{21}$

a. Dimensi Kepribadian Sebagai Manusia, yaitu kemampuan untuk menjaga integritas, termasuk sikap tingkah laku, etika dan moralitas yang sesuai dengan pandangan masyarakat.

b. Dimensi Produktivitas, yang menyangkut apa yang dihasilkan oleh manusia tadi, dalam jumlah yang lebih banyak dan kwalitas yang lebih baik.

c. Dimensi kreativitas, yaitu kemampuan seseorang untuk berfikir dan berbuat kreatif, menciptakan sesuatu yang berguna bagi dirinya dan masyarakatnya.

Ketiga dimensi terdsebut merupakan pokok persoalan yang perlu mendapat perhatian dalam upaya meningkatkan kwalitas sumber daya manusia kita. Akan tetapi semua dimensi yang disebutkan diatas, sangat perlu untuk mendapatkan pendampingan nilai spiritual, hal itu mengingat bahwa manusia merupakan makhluk yang secara fitrah diciptakan untuk menyembah penciptanya melalui cara yang telah ditetapka oleh agama Islam.

${ }^{21}$ M. Thalhah Hasan, Islam Dan Masalah Sumber Daya Manusia, Lantabora Press, Jakarta Selatan, 2003. Hal. 60 
Adapun tujuan dari pembenahan Sumber daya manusia dapat dikatakan berhasil apabila mampu memenuhi tiga kriteria berikut $:^{22}$

1. Kreatif secara konseptual, yaitu mampu mengembangkan gagasan, ide-ide dan konsep yang cemerlang.

2. Kreatif secara social, yaitu dapat melakukan pendekatan dan terobosanterobosan kemasyrakatan yang strategis.

3. Kreatif secara spiritual, yaitu mampu mengembangkan krakter kemanusiaan yang bertaqwa, berakhlaq dan berkepekaan manusiawi.

Indikator-indikator yang disebutkan diatas sudah termasuk pada indikator yang standarisasinya bisa dibilang cukup tinggi karena meliputi berbagai aspek yang apabila mampu dipenuhi akan melahirkan manusiamanusia yang Kreatif, Produktif dan Berkepribadian.

Apabila dibawa dan difokuskan pada ranah dakwah, Indikatorindikator diatas dapat dijabarkan sebagai berikut:

1. Kreatif secara konseptual, yaitu para da'i mampu mengembangkan gagasan, ide-ide dan konsep yang cemerlang mengenai content, metode dan media dakwah sehingga mampu melahirkan sebuah terobosan-terobosan yang bisa membuat dakwah berjalan secara maksimal dan efektif dalam mencapai tujuannya. Seperti misalnya mampu merumuskan pembuatan content islami yang up to date sesuai dengan apa yang menjadi trend pada waktu itu dan zaman yang akan datang.

2. Kreatif secara social, yaitu para da'i mampu melakukan pendekatan dan terobosan-terobosan kemasyrakatan yang strategis, sehingga mampu membentuk lingkungan dan komunitas islami -baik dalam dunia nyata maupun dalam dunia digital, seperti Komunitas Online- seperti apa yang menjadi tujuan dakwah. Apabila dilihat dari mad'u, maka kreatif secara social dapat diartikan sebagai seuatu kemampuan dari mad'u dalam memberikan komentar dan mempromosikan postingan-postingan dakwah melalui eWOM atau dengan men-Share sehingga bisa menjadi nilai tambah dari apa yang disampaikan oleh da'i, yang pada akhirnya akan mampu menjadi kepanjangan tangan dari da'i untuk ikut serta dalam menyampaikan pesan dakwah.

3. Kreatif secara spiritual, yaitu para da'i memiliki pengalaman spiritual yang cukup sehingga mampu menajadi contoh panutan yang istiqomah dan bisa mengembangkan krakter kemanusiaan yang bertaqwa, berakhlaq dan berkepekaan manusiawi memalui pesan dakwah yang sarat dengan nilai-nilai agama.

\section{Solusi Pemecahan Problem Dakwah Era ICT}

${ }^{22}$ Ibid, 70 . 
Dakwah merupakan fenomena keagamaan yang bersifat ideal normative sekaligus juga merupakan fenomena social yang rasional, actual dan empiris sebagai sunnatullah. Oleh karena itu dakwah berkaitan erat dengan semua ilmu pengatahuan dan teknologi. Hal tersebut sejalan dengan pandangan bahwa dakwah merupakan amal sholeh (syariah dan akhlak) yang bersumber dari iman (aqidah), takwa (aresiasi ke-Tunanan) dan Islam (penyerahan diri) yang harus dilaksanakan sesuai dengan sunnatullah yang dipahami manusia dalam bentuk ilmu pengetahuan. ${ }^{23}$

Berangkat dari dimensi dakwah seperti dijelaskan diatas, maka seorang da'i dituntut memiliki pengetahuan media dan teknologi yang memadai sebagai penunjang dari kecakapan individu, kecakapan dimaksud tidak terbatas pada kepiawaian dalam menciptakan konsep dakwah yang menarik, metode yang baik, ataupun pesan dakwah yang mudah diterima, akan tetapi seorang da’i dituntut juga untuk memiliki "kelebihan" yang lebih dari itu semua, termasuk diantaranya cakap dalam memanfaatkan Media \& ICT. Hal itu dimaksudkan karena penguasaan media dakwah menjadi salah satu penentu tercapainya tujuan dakwah secara efektif dan efisien. ${ }^{24}$

Secara sederhananya dapat dijelaskan sebagai berikut, orang yang sangat pandai dan memilki kreatifitas tapi tidak cakap dalam menggunakan media \& ICT, pasti dia akan tertinggal, minimal kreatifitasnya tidak bisa di expose secara luas dan tidak bisa di nikmati banyak kalangan dan bahkan akan kalau up to date dengan kreatifitas orang lain. Asumsi ini berdasarkan pada fakta bahwa semua "yang baru" -baik penemuan, prilaku, maupun life style- bisa di temukan di internet dalam setiap detik, bahkan second. Sehingga mau ataupun tidak, siapapun yang ingin dianggap kreatif harus bisa secepatnya meng-upload hasil kreatifitasnya dalam media social sebelum didahului oleh orang lain.

Maka sebagai solusi awal untuk mempercepat peran serta dakwah dalam mengimbangi kemajuan media \& ICT, diperlukan adanya kolaborasi antara anak-anak muda yang cakap secara pengetahuan teknologi dengan para da'i "sepuh" yang memiliki kompetensi dalam menggali intisari pengetahuan dan tuntunan religius dari al-qur'an dan al-hadits.

Sedangkan sebagai solusi jangka panjang, harus ada upaya kongkrit yang sistematis dari semua penggiat dakwah untuk berperan aktif dalam menggali potensi diri dengan terus belajar dan mengasah diri dalam segala bidang yang diperlukan untuk mensukseskan proses tranformasi pesan dakwah dalam bentuk konten yang familiar dan di lekat dengan kehidupan mitra dakwah. Hal diatas sangat perlu untuk diperhatikan, karena adanya pergeseran yang

${ }^{23}$ Anwar Arifin, Dakwah Kontemporer Sebuab Studi Komunikasi, Graha Ilmu, Yogyakarta, 2011, Hal. 16

${ }^{24}$ Onong Uchana, Ilmu Komunikasi: teori dan praktek, Bandung: Rosda Karya, 2009, hal . 19 
cukup jauh pada tata kehidupan masyarakat modern yang semua aktivitasnya memanfaatkan media \& ICT.

\section{Penutup}

Dari semua yang sudah di jelaskan diatas, maka punulis bisa menarik beberapa kesimpulan, yaitu : Perkembangan Media \& ICT telah merubah pola dan gaya hidup masyarakat. Tata hidup masyarakat modern cenderung lebih "kacau" apabila dibandingkan dengan kehidupan masyarakat taradisional yang disebabkan keterbukaan informasi yang tidak terkontrol secara maksima. Problematika kehidupan yang dihapi masyarakat semakin komplek, dan harus di imbangi dengan konten dan metode dakwah yang variatif. Pengembangan SDM pendakwah merupakan suatu keniscayaan.

\section{DAFTAR PUSTAKA}

Abraham,M. Francis. (1991). Modernisasidi Dunia Ketiga Suatu Teori Umum Pembangunan. (Terjemahan M. Rusli Karim). Penerbit :University Press of America,(Buku asli diterbitkan tahun 1980).

Al-qur'an Digital Bahasa Indonesia, versi 3. 9.2

Amin, Samsul Munir, Ilmu Dakwah, (Jakarta: Amzah, 2009)

Arifin, Anwar, Dakwah Kontemporer Sebuah Studi Komunikasi, Graha Ilmu, Yogyakarta, 2011

Azis,Ali. Ilmu Dakwah Edisi Revisi, Kencana, Jakarta,2009.

Bungin, Burhan, Sosiologi Komunikasi: Teori, Paradigma, dan Diskursus Teknologi Komunikasi di Masyarakat. Jakarta: Kencana. 2007

E-journal, Part 3/8 Industry Transformation - Horizon Scan: ICT \& the Future of Media

Hasan, M. Thalhah, Islam Dan Masalah Sumber Daya Manusia, Lantabora Press, Jakarta Selatan, 2003.

Ilaihi, Wahyu. Komunikasi Dakwah, (Bandung: Pt. Remaja Rosdakarya, 2010)

Kompas. com. (29Januari2013). Narkoba Kian Merajalela, Terpidana Mati Kendalikan Pasar.

Mc Luhan, Marshal. 2003"Technology Determinism", In A First Look at Communication Theory, Fifth Edition, by EM Griffin, New York, Mc Graw Hill. 2003.

Muhammad Abubakar, Membangun manusia seutubnya menurut al-qur'an, al-Ikhlas, Surabaya, tt. 
Muzaini, Perkembangan Teknologi Dan Perilaku Menyimpang Dalam Masyarakat Modern, Jurnal Pembangunan Pendidikan: Fondasi dan Aplikasi Volume 2, Nomor 1, 2014

Nuruddin, Media Sosial Baru dan Munculnya Revolusi Proses Komunikasi, Jurnal Komunikator UMY : Vol. 5, no. 2,127-142, November 2013

Part 3/8 Industry Transformation - Horizon Scan: ICT \& the Future of Media

Shihab, M. Quraiys, "Membumikan" Al-Qur'an", Mizan, Bandung, cetakan XXVII, 2004

Tamzil, Fachmi. Peran Teknologi Informasi Dalam Dunia Komunikasi, Universitas Esa Unggul - http://www. esaunggul. ac. id, 09-03-2012

Thorsten Hennig-Thurau, Edward C. Malthouse, Christian Friege, Sonja Gensler, Lara Lobschat, Arvind Rangaswamy, and Bernd Skiera, The Impact of New Media on Customer Relationships, Journal of Service Research13(3) 311-330

Uchana, Onong. Ilmu Komunikasi: teori dan praktek, Bandung: Rosda Karya, 2009. Yusuf bin Abdillah bin Muhammad bin Abdi al-Barri, Abû Umar, al-tambid Limâ fi Al-Munattho' min Ma'âni wa Al-Asanîd, Maktabah Ibnu Taimiyah 